\title{
The UN in the Congo conflict: ONUC
}

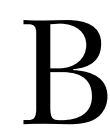

ETWEen 1960 AND 1964, the UN conducted one of the most controversial peacekeeping operations in its history. ONUC $^{1}$ drew on 93,000 personnel from 34 states. $^{2}$ It involved 19,828 personnel at its peak, ${ }^{3}$ and cost US\$400,130,793, provoking a serious financial crisis for the UN. ${ }^{4}$ The Congo case is interesting for our purposes not only because it aroused immense controversy, but also because the UN was 'entrapped' by a complex web of interlocking crises with obvious inter-state and intra-state dimensions.

In the Congo, the UN was originally expected to respond to an inter-state conflict that emerged out of the decolonisation process, but soon found itself in the position of having to redefine the principles of its involvement. Our examination will in particular focus on the shift from inter-state to intra-state peacekeeping, with the international response to secessionist attempts acting as a bridge between the two. Once the internal dimension of the conflict was made part of the UN's agenda, as the last part of our analysis will demonstrate, the UN would be given more and more authority to handle the crisis.

Even a preliminary reading of the ONUC experience clearly demonstrates that it was not 'typical' of its period. The UN's Congo mission was far more ambitious than any peacekeeping mission hitherto. Nevertheless, it is precisely the ambitious nature of the mission that makes it instructive for our purposes. We know, for instance, that the UN used force in the Congo. But what precisely were the objectives and underlying dynamics of the operation? What exactly was the extent and scope of the authority assigned to the UN in this, the 'boldest' intra-state peacekeeping mission of the 1960s? It is primarily to these questions that this chapter will now turn its attention.

\section{Historical background}

Colonised by Belgium in the 1880 s, ${ }^{5}$ the Congo's great attraction was its mineral wealth. These resources were especially plentiful in the southern provinces of 
Katanga (provincial capital: Elisabethville) and Kasai (provincial capital: Luluabourg). ${ }^{6}$ In 1906 the Belgian company Union Minière du Haut Catanga was given exclusive mining rights in Katanga until 1999. ${ }^{7}$ While the Belgian colonialism was oppressive, local resistance to it did not mature until the second half of the 1950s. ${ }^{8}$ In January 1960, to the surprise of Congolese leaders, Belgium agreed to grant independence to the Congo as early as 30 June $1960 .{ }^{9}$

The ensuing elections failed to produce a politically well organised Congolese Parliament. ${ }^{10}$ Consisting of some 70 ethnic groups, the Congolese body politique was characterised by strong communal and regional networks and loyalties. Within this complex cultural and political mosaic, personalities played a far more significant role than the embryonic political organisations. Eventually, on 23 June 1960, the two rival dominant Congolese leaders were elected to the two key positions: Joseph Kasavubu became President ${ }^{11}$ and Patrice Lumumba Prime Minister. ${ }^{12}$ On 30 June 1960, as planned, the Congo became independent.

On 11 July, Katanga proclaimed its own independence under Moise Tshombé's leadership, ${ }^{13}$ and Belgium more or less simultaneously strengthened its military bases in the Congo. For obvious economic reasons, Belgium did not want to lose the Congo, especially Katanga. Having granted the Congo its independence, the Belgians, who had hoped to retain their privileges for some time, were surprised to find that the Congolese Government wanted them to pull out of the country immediately. Belgian interests and Belgian expatriates in the Congo were clearly not reconciled to an early departure from the former colony. However, in the midst of independence euphoria, and with violent attacks on local Belgians on the rise, Belgium found the necessary pretext for its 'humanitarian' intervention in the Congo. The North-South conflict was visible from the outset of the crisis.

\section{UN involvement without a 'prelude'}

The UN's formal involvement in the Congo crisis began in response to the Belgian presence in the former colony, and came into being quite suddenly. On 17 July 1960, Kasavubu and Lumumba addressed an ultimatum to the Secretary-General, warning that if the Belgian forces were not completely withdrawn within 48 hours, they would request troops from the Soviet Union. From that moment on, the Cold War would make its presence felt in the Congo.

The initiative to prevent the emergence of a crisis came from Hammarskjöld. The situation had already attracted great interest from a number of international actors. For the West the atrocities committed against foreigners (mainly Belgians) were of particular concern. So were the strong financial, political and strategic ties between Belgium and other western countries. For the Soviet bloc, on the other hand, the upheaval in the Congo provided a perfect opportunity to 
demonstrate the 'imperialist' tendencies of western policies. To this extent at least, the Secretary-General's initiative met with little opposition. The international community was willing to 'do something'.

\section{'Peacekeeping' against foreign intervention}

The original authorisation of $\mathrm{ONUC}^{14}$ came in response to official approaches by Lumumba and Kasavubu ${ }^{15}$ who made it clear that their request for aid was to counter external aggression and 'not to restore the internal situation'. ${ }^{16}$ The ensuing resolution treated the Congo crisis as an inter-state conflict. Its first operative paragraph called upon Belgium to withdraw its troops from the Congo. It identified the key problem as the unwanted presence of the troops of a member state within the territory of another independent state. ${ }^{17}$

The second operative paragraph would present considerable difficulties during the later stages of the mission:

The Security Council,

2. Decides to authorize the Secretary-General to take the necessary steps, in consultation with the Government of the Republic of the Congo, to provide the Government with such military assistance as may be necessary until, through the efforts of the Congolese Government with the technical assistance of the United Nations, the national security forces may be able, in the opinion of the Government, to meet fully their tasks;

First, it should be noted that it was the Secretary-General who, acting on behalf of the Security Council, would determine what those necessary steps were. ${ }^{18}$ In the person of the Secretary-General the UN was given a prominent role in managing the ongoing conflict. This would prove a crucial source of discontent in the later phases of the operation. Secondly, the UN declared that it was dealing with the Government of the Congo. Once the intra-state dimension of the conflict came to dominate the crisis, this provision would create a major obstacle. Thirdly, the Security Council ruled out any neutral assessment of the efficiency of the Congolese security forces. Instead, it undertook to provide assistance until such time as the Congolese Government deemed its security forces equal to the task. This formulation was shaped in relation to the external dimension of the Congo crisis. Once the internal dimension came to the forefront, this original formulation would pose a serious handicap. The UN's resources were placed at the disposal of the Congolese Government, which would, however, soon become an 'internal' party to an intra-state crisis, and would use this provision to its own benefit in the civil war.

A strong disagreement soon emerged within the Security Council as to whether the first operative paragraph (i.e. Belgian withdrawal) depended on the second (i.e. UN guarantee of law and order). The Soviet Union, Poland, 
Tunisia, Ecuador, and Ceylon argued that an act of aggression had occurred, and pressed for the unconditional withdrawal of Belgian forces. The US representative categorically rejected the charges of aggression, ${ }^{19}$ while the United States, Britain, France and Italy emphasised the humanitarian reasons for Belgian intervention, and held that contingency existed between the paragraphs. Unless law and order could be guaranteed, Belgium could not be expected to withdraw. In fact, the West found the first operative paragraph totally unnecessary. ${ }^{20}$ This was perhaps the first crucial moment when the strong anti-colonial voices of the Third World had overlapped with the views of the socialist bloc against the colonial powers which were for the time being backed by their strongest ally, the United States.

In the end, the resolution was passed without a clear Security Council position as to the problem of conditionality. The first operative paragraph did remain in the text. Without it, the Soviet Union would have resorted to a veto. From the Soviet perspective, this provision embodied the minimum of what it considered an acceptable resolution. On the other hand, Britain, France, Taiwan and the United States could have vetoed the resolution, had Hammarskjöld pressed for collective sanctions against Belgium. Three Soviet amendments to the Tunisian draft had already been rejected. ${ }^{21}$ The Security Council's call to Belgium was therefore a balancing act between two extremes.

Rikhye maintains that Hammarskjöld dominated the decision-making process during the formulation of the original mandate. ${ }^{22}$ Through his efforts the major powers eventually came to agree on the somewhat ambiguous wording of ONUC's mandate. On the one hand, to secure western support for the authorisation of the operation, Hammarskjöld insisted from the outset that the sole basis for UN jurisdiction was the request by the Congolese Government for UN assistance, and not a state of hostilities between two states. ${ }^{23}$ Hammarskjöld publicly maintained that Belgians would withdraw as soon as the UN force established law and order in their former colony. After all, Belgians had claimed that they intervened strictly because of their 'sacred duty to protect the lives and honour' of their fellow-citizens. ${ }^{24}$ For the Soviet Union, on the other hand, the wording of the mandate alluded to the UN's enforcement role. Both the Congolese Government and the Soviet Union had consistently accused Belgium of aggressive behaviour. ${ }^{25}$ In other words, the UN force had to do what the UN was constitutionally supposed to do against acts of aggression. Consistent with the Government's request, ONUC had to ensure, by whatever means necessary, Belgium's immediate withdrawal.

\section{Consensual focus on external dimension: SC Resolution 145}

The second SC resolution came within ten days of the first one. ${ }^{26}$ This resolution, too, dealt with the external dimension of the crisis. The main difference 
with Resolution 143 was embodied in its second operative paragraph: ${ }^{27}$

The Security Council,

2. Requests all States to refrain from any action which might tend to impede the restoration of law and order and the exercise by the Government of the Congo of its authority and also to refrain from any action which might undermine the territorial integrity and the political independence of the Republic of the Congo;

The resolution established a clear link between internal unrest in the Congo and external interference. While this conception parallelled the view reflected in SC Resolution 143, this time the identity of the perceived parties to the conflict was blurred. Belgium, as conceded in the first paragraph, was clearly a party to the crisis. A second party, undoubtedly, was the Congolese Government. Yet acknowledgment was also given to the possibility that there were more state parties to the conflict. The support extended by the surrounding French and British colonies to Katanga was not unknown. Rhodesia, for instance, consistently supplied the Province with weapons. ${ }^{28}$ More importantly, however, the resolution reflected the mutual suspicion of the two blocs. Both the United States and the Soviet Union were fearful of each other's possible direct involvement in the Congo. In adopting the second operative paragraph, then, the superpowers had acquired the legal right to criticise each other's activities in the Congo if the need arose.

On the other hand, the paragraph for the first time referred to the 'restoration of law and order' in the Congo - a phrase which was absent in Resolution 143. From the context it is clear that these words were not intended to address the intra-state dimensions of the conflict per se. Instead, the Security Council was trying to establish a link between domestic problems and external interference. In other words, the problem was still perceived to be the difficulty the legitimate and supposedly cohesive Congolese Government had in maintaining domestic law and order in the presence of external interference. ${ }^{29}$ By putting the emphasis on the Congo's territorial integrity and political independence, the paragraph unambiguously conveyed the UN's primary normative objective, namely protection of the Congo's (external) sovereignty. From the perspective of the Second and Third Worlds, the key question was that of independence. The only relevant 'enemies' of territorial integrity were foreign powers with (neo)colonial ambitions.

SC Resolution 145 remained the only resolution on the Congo crisis that was unanimously adopted, without abstentions. It embodied the uneasy collective view of the Security Council on the matter, which emerged as a compromise between radically antagonistic positions. As we shall see below, the more the internal aspect of the crisis came to the fore, the more disagreements emerged between members of the Security Council as to how the 
resolutions should be interpreted and what the UN's objectives and authority should be.

Although consensual, the Security Council's emphasis on the external dimension of the crisis emanated from two different positions. For the Soviet bloc and some Third World countries, the resolution could not have any other emphasis, because the whole crisis was the result of colonial ambitions. From the western viewpoint, on the other hand, the UN's responsibilities did not extend to intra-state aspects of the crisis. Neither the Congo's original request nor the Security Council's response entailed any UN commitment to deal with the domestic problems of the Congo. Furthermore, the principle of non-intervention hindered such commitment. ${ }^{30}$

The direct Belgian intervention largely came to an end by early September 1960. ${ }^{31}$ However, the problem of unwanted foreign presence and activities did not evaporate. In conjunction with secessionist attempts, the issue of mercenaries continued to occupy the UN's agenda. Despite the official Belgian withdrawal, many Belgian military personnel remained in Katanga, transforming themselves into mercenaries in charge of the Katangese gendarmerie, ${ }^{32}$ thereby making it very difficult for the UN to establish a formal link between Belgian intervention and the Katanga question. ${ }^{33}$

\section{Where 'external' meets 'internal': attempts at secession}

Katanga's proclamation of independence predates the authorisation of ONUC. Similarly, Kasai's intention to become independent was made known during the first parliamentary discussions. ${ }^{34}$ However, these secessionist movements did not enter ONUC's agenda until mid-August 1960. Tshombé declared that Katanga would resist by every means ONUC's entry into the province. Meanwhile, South Kasai proclaimed its own secession in August under Albert Kalonji's leadership. ${ }^{35}$

Embarking on a diplomacy of persuasion in Katanga, Hammarskjöld arrived in Léopoldville, and sent his Special Representative, Ralph Bunche (a US citizen), to Elisabethville to make arrangements for ONUC's entry into the province. His argument was that ONUC personnel were under the sole command and control of the UN. ${ }^{36}$ ONUC was not permitted to intervene in the internal affairs of the country where they were deployed, and hence could not prejudice Katanga’s position vis-à-vis Léopoldville. Moreover, UN peacekeepers were not entitled to use force except in self-defence. Yet ONUC's mandate applied to the whole of the Congo, including Katanga. If, despite his assurances, ONUC were denied entry, he would call an immediate Security Council meeting. Tshombé refused and Hammarskjöld duly called a meeting. ${ }^{37}$ At about the same time, on 6 August, Lumumba's written complaint to the Security Council, and Ghana's and Guinea's criticisms of the 
UN, led the Soviet Union to demand the removal of all Belgians from the Congo 'by recourse to whatever method of action' was necessary. ${ }^{38}$ The UN was now explicitly called upon to use force against Belgian troops.

\section{Gradual recognition of the internal dimension: SC Resolution 146}

The ensuing debate led to the adoption of SC Resolution 146 on 9 August 1960 , by 9 votes to 0, with France and Italy abstaining. Before SC Resolution 146, the Katanga case had not been specifically addressed by the Security Council. The emphasis of the Security Council on the external dimension of the conflict now began to shift. In line with previous resolutions, the Security Council stuck to the view that complete Belgian withdrawal from the Congo and the establishment of an effective government were both necessary. In other words, the Security Council in its collective capacity remained committed to its previous position which had emphasised the territorial integrity and political independence of the Congo. ${ }^{39}$

SC Resolution 146 reaffirmed that ONUC would 'not be a party to or in any way intervene in or be used to influence the outcome of any internal conflict, constitutional or otherwise' ${ }^{40}$ This was a re-statement of the Charter principle of non-intervention embodied in Article 2.7. Here we find not only an expression of Hammarskjöld's doctrine of impartiality/neutrality, but also the first indicator that internal unrest in the Congo was entering the UN's formal agenda. The Resolution embodied mainly Hammarskjöld's views, which for the time being suited the West's interests. The UN's impartiality visà-vis internal parties meant in concrete terms that ONUC would not disregard the views of Katanga and Kasai. This provision was especially welcome to Britain, which had cast an affirmative vote for the resolution. In other words, the UN's impartiality vis-à-vis the immediate parties to the conflict signified its neutrality vis-à-vis the North-South and the East-West conflicts. There were strong structural constraints on the normative basis of UN action.

Up until that point, the Security Council had defined its own role purely in relation to a perceived inter-state conflict. In one sense, nevertheless, the Security Council's overall attitude was quite revolutionary, since the conflict in question had emerged out of the process of decolonisation. While considerable political and normative differences separated individual members' positions, the net effect was that the Security Council, in its collective capacity, had endeavoured to create a sovereign state out of a former colony, at least on paper and in principle. Third World opposition to colonialism was so strong that it impacted on the UN's normative attitude at least as much as the East-West conflict did.

By the time discussions got under way, Belgium had already agreed not to resist ONUC's entry into Katanga, albeit reluctantly and under considerable 
pressure. ${ }^{41}$ It was Tshombé and his team who were determined not to cooperate. Yet Hammarskjöld was steadfastly refusing to use force to enter Katanga. A Soviet proposal that the Secretary-General be ordered to take all necessary means of enforcement to expel the Belgians ${ }^{42}$ was opposed by Hammarskjöld, and did not find support among western members. The continuing emphasis on the external dimension of the crisis, that is, Belgian withdrawal, no doubt accounts, at least in part, for the Soviet Union's eventual decision to vote in favour of a Ceylon-Tunisia draft. Italy and France abstained on the grounds that Belgian withdrawal was not a necessary concomitant of the UN's law and order role. ${ }^{43}$ The French delegate had explicitly pronounced his Government's position when in the course of discussion he posed the question: 'Which of our governments would have acted differently if it had been placed in the same position [with Belgians]?'44

The adoption of Resolution 146 proved a turning point for the UN's Congo operation. It was interpreted in two radically different ways. To Lumumba, who welcomed the resolution, it meant that the UN together with the Central Government would end Katanga's secession. The Soviet Union, consistent with its longstanding attitude, interpreted the resolution as direct UN support for the cause of the Central Government, and voted in favour. At this stage, Soviet insistence on the need for the UN to support the 'Central Government' not only accorded with the letter of SC resolutions, but it also strengthened the slowly emerging normative view (supported by an increasing number of Third World states, and opposed mainly by the former colonial powers) that the UN should be at the service of the Central Government to protect the Congo's sovereignty against external intervention. After Mobutu's coup d'état, when the Central Government was no longer in Lumumba's hands (see below), this normative preference would begin to work against the Soviet bloc which would then shift its position to supporting the 'legitimate' Congolese Government. ${ }^{45}$

In Hammarskjöld's view, on the other hand, ONUC had to avoid collaboration with any party so far as an intra-state conflict was concerned, hence the need to adhere to the strict principle of non-intervention. ONUC had entered the Congo at the request and in support of the Central Government against an unwanted foreign presence, but not against any internal 'threats'. On 12 August 1960, Hammarskjöld drew Lumumba's attention to previous crises where elements of an external nature had combined with elements of an internal nature. ${ }^{46}$ Part of his Interpretation of Paragraph 4 is worth quoting at length:

The United Nations is directly concerned with the attitude taken by the provincial government of Katanga to the extent that it may be based on the presence of Belgian troops ... [Resolution 146], which reaffirmed the principle of non- 
intervention, put the main emphasis on the withdrawal of Belgian troops. Therefore ... if the Belgian troops were withdrawn ... the question between the provincial government and the central government would be one in which the United Nations would in no sense be a party and on which it could in no sense exert an influence. It might be held that the United Nations is duty bound to uphold the Fundamental Law ${ }^{47}$ as the legal constitution and, therefore, should assist the central government in exercising its power in Katanga. However, the United Nations has to observe that, de facto, the provincial government is in active opposition - once a Belgian assurance of non-intervention and withdrawal has been given - using only its own military means in order to achieve political aims. ${ }^{48}$

The Secretary-General considered each of the internal parties as equally legitimate. All along his efforts had been directed at cutting off the close links between external third parties on the one hand and internal parties on the other. That the UN should maintain general law and order in the Congo meant in Hammarskjöld's view the elimination of foreign intervention. Beyond that, however, the UN had no right to engage in direct support either of the Central Government or of the opposition. Expressed more concretely, the UN could not be expected to transport, protect, aid or in any way favour any of the parties to the conflict.

Hammarskjöld envisaged a role for the UN focusing solely on the international dimension of peace and security. While he was aware of the continuing domestic upheaval in the Congo, at the normative level he was convinced that the internal dimensions of the conflict should be handled quite separately from its international dimensions. At the analytical level he assumed that such a distinction was possible. Although he consistently tried to hold to this interpretation all through the crisis, his position stood in contrast not only to the Soviet view, but also to the rhetoric of the first two $\mathrm{SC}$ resolutions analysed above. As we have seen, Resolution 143 in particular implied that Security Council action was based entirely on the consent of the Central Government. Indeed, one of Lumumba's criticisms of Hammarskjöld would be that the Secretary-General had ignored the original mandate given to ONUC 'to provide the Government with such military assistance as may be necessary'. ${ }^{49}$

The Secretary-General's attitude led to harsh criticisms from the Soviet bloc which insisted that the secession attempts were not even remotely 'internal' in substance, from which it followed that Hammarskjöld's policy of impartiality or non-intervention were merely serving colonial interests. ${ }^{50} \mathrm{In}$ mid-August the Soviet Union started to provide arms to the Central Government. Some of its supporters (e.g. Ghana) warned that they would take independent action, unless the UN faithfully carried out its mandate, which they interpreted as ensuring the political independence and territorial 
integrity of the Congo, by whatever means necessary. In an unambiguous case of aggression, which was clearly within the purview of the UN Charter, the UN had only one course of action open to it - to impose international peace and security. To insist that ONUC should remain neutral and not intervene, the Soviet view implied, was tantamount to insisting that the UN permit violation of the Congo's sovereignty. In other words, the UN would need to abandon the norms of impartiality/neutrality and non-intervention for the sake of protecting the Congo's sovereignty which was ONUC's foremost normative objective. ${ }^{51}$

\section{Towards UN intervention in 'domestic' affairs}

In the wake of mounting criticism, the Secretary-General called a Security Council meeting on 21 August, which made it clear that the socialist bloc now directly opposed Hammarskjöld's policy of non-intervention. The Polish representative stated that everyone agreed that the organisation should not interfere in disputes between the Congolese Government and provincial authorities, if these disputes were indeed internal in character. Since in Katanga complete authority rested with the Belgians, he held, the UN should apply the doctrine of restitutio in integrum, and restore the conditions before the illegal Belgian actions took place, ${ }^{52}$ that is the Congo's unity. During this meeting, the Secretary-General made known his intention to appoint an 'Advisory Committee' consisting of the troop contributing countries.

Upon the adoption of SC Resolution 146, Hammarskjöld was finally able to enter Katanga to negotiate ONUC's entry into the province. Lumumba was not pleased with Hammarskjöld's approach, for he had chosen to ignore the wishes of the Central Government, and preferred to deal directly with Tshombé. ${ }^{53}$ The Secretary-General had also refused to take along any Government troops or officials during his visit to Katanga. The Government was now planning to end both secession attempts by force - a decision which added to the tension between ONUC and the Government. ${ }^{54}$ Although ONUC did not have a specific mandate to maintain 'internal' law and order, it was thwarting the Government's decision to exercise its 'sovereign right' to maintain its territorial integrity by coercive measures. Before long, Congolese National Army (ANC) troops entered South Kasai. Many civilians, mostly Baluba, were killed.

\section{The 'Constitutional Crisis'}

By early September, a serious conflict had emerged between the President and the Prime Minister, the immediate reason for which was Lumumba's bloody operation in South Kasai. On 5 September, President Kasavubu dismissed 
Prime Minister Lumumba and replaced him with Joseph Ileo. ${ }^{55}$ This led to a chaotic situation where even the legality, let alone the legitimacy, of the new government was in question. This so-called 'Constitutional Crisis' would in subsequent months become a significant component of the Congo crisis.

On 6 September, with a view to maintaining law and order, ONUC took a number of emergency measures, including the closing of the Léopoldville airport and radio station. ${ }^{56}$ This action deprived Lumumba, whose charisma had appeal in all parts of the Congo, of the means to explain the situation and seek active support for his cause. ${ }^{57}$ On the military side, the measures also prevented Lumumba from using his aeroplanes in his campaign against Katanga. Thus, ONUC's action was considered by the Soviet bloc as an antiLumumba effort. Although with the easing of tension the measures were lifted the following week, ONUC had now in effect actively 'intervened' in the domestic affairs of the Congo.

By September 1960, Hammarskjöld's policy of non-intervention was working completely against ONUC. On one side, Lumumba and the Soviet Union were accusing Hammarskjöld of complete partiality. On the other side, Kasavubu was accusing the UN of still dealing with Lumumba's illegal authority. For its part, the United States was intent on conferring total legitimacy on Kasavubu. The Congo's internal politics was increasingly incorporated into the Cold War, with Lumumba representing the aspirations of the Soviet bloc and Kasavubu those of the West. ${ }^{58}$

On 14 September, Joseph Mobutu led a coup d'état. ${ }^{59}$ He neutralised Kasavubu and Lumumba, dismissed Ileo's government, and declared that the country would be run by a Collège des Universitaires. ${ }^{60}$ Taking this opportunity to get rid of Lumumba, Kasavubu cooperated with the new regime, and converted the College into a 'Council of Commissioners' - a move welcomed by the West since Lumumba was thereby removed from office. Under the Mobutu-Kasavubu arrangement, the Soviet and Czech missions in Léopoldville were closed, and Soviet technicians in Stanleyville were asked to leave. The Cold War had now fully penetrated the intra-state conflict in the Congo.

On 14-17 September 1960, the Security Council held an urgent meeting to discuss the situation. A Ceylon-Tunisia draft, ${ }^{61}$ which reflected the Secretary-General's recommendations, was vetoed by the Soviet Union. Eventually, despite Soviet accusations of illegal action, a US draft resolution, ${ }^{62}$ calling an emergency special session of the General Assembly, was adopted. The Soviet Union and Poland voted against the resolution. France abstained.

The emergency special session followed immediately. On 20 September, GA Resolution 1474, sponsored by 17 Afro-Asian states, ${ }^{63}$ was finally adopted by 70 votes to 0 with 11 abstentions including the Soviet Union and France. It contained several provisions embodied in the Ceylon-Tunisia draft 
recently vetoed by the Soviet Union in the Security Council. This resolution was perhaps the first concrete sign that the hitherto adopted normative rhetoric was beginning to work against the political preferences of the Soviet bloc:

The General Assembly,

2. Requests the Secretary-General to continue to take vigorous action in accordance with the terms of the aforesaid resolutions and to assist the Central Government of the Congo in the restoration and maintenance of law and order throughout the territory of the Republic of the Congo and to safeguard its unity, territorial integrity, and political independence in the interests of international peace and security; ${ }^{64}$

As we have already seen, from the outset of the UN mission, the Soviet Union consistently argued that ONUC would have to be at the service of the Central Government. Now that the Central Government was taken over by a 'hostile' regime as a result of an internal power struggle, the Soviet bloc would adopt a new line of normative argument by putting the emphasis on the 'legitimate' Congolese government. By increasingly encouraging UN action against the Central Government, the Soviet Union would then help to shape an 'interventionist' UN attitude. This new approach would find its expression in SC Resolution 161, which, as we shall see below, would not even once refer to the 'Central Government', and which would task ONUC with prevention of civil war in the Congo.

GA Resolution 1474 not only requested the Secretary-General to continue to take 'vigorous' action, it also called upon member states to refrain from giving direct or indirect military assistance to the parties except at the UN's request. ${ }^{65}$ Furthermore, it called for the establishment of a body to assist the Congolese factions specifically in the settlement of their 'internal' conflict. ${ }^{66}$ The resolution in its entirety assigned exclusive authority to the UN for handling the crisis. Again, Third World voices were crucial in the re-definition of the UN's role.

The creation of the so-called Conciliation Commission is important in two respects. First, it highlights the belief of the UN membership that the internal and external aspects of the ongoing crisis were distinct from each other. Secondly, it confirms that the majority of members eventually prescribed a role for the UN beyond protection of 'external' sovereignty. This point has serious implications for the principle of non-intervention. In relation to this latter point, the Soviet Union had argued in the General Assembly that the Congolese might interpret the proposed line of action as interference in their internal affairs. ${ }^{67}$ Similarly, France had objected strongly to the UN addressing the internal problems of the Congo. ${ }^{68}$ Nevertheless, a great many Third World countries, several of them non-aligned, were now willing to tolerate a minimum level of UN intervention in the Congo's 'internal' affairs for the sake 
of maintaining 'international' peace and security in the face of the rapidly escalating bipolar rivalry.

Three days after the special emergency session, the General Assembly convened for its regular annual session, with the participation of 32 heads of state or government. ${ }^{69}$ The Credentials Committee had to decide who would represent the Congo. Guinea's proposal that the seat be occupied by the representatives of the Lumumba Government was endorsed by seven other Afro-Asian countries with contingents in ONUC, ${ }^{70}$ and supported by the Soviet Union. Argentina, reflecting the western view on the issue, opposed seating Lumumba's representatives. In the end, the General Assembly ruled in favour of Kasavubu's representatives, ${ }^{71}$ a result which favoured the AngloAmerican position. In effect, the Mobutu regime had been legitimated by the UN. An important minority, including the troop-contributing African countries and the Asian neutralists, remained opposed to this decision. A number of countries, which had a special interest in UN peacekeeping, were unconvinced and abstained. ${ }^{72}$

In his speech of 23 September, Khrushchev attacked the 'imperialist' powers, which had 'been doing their dirty work in the Congo through the Secretary-General of the United Nations and his staff' ${ }^{73}$ He targeted not only the person of Hammarskjöld but also the office of the Secretary-General, and proposed an alternative executive body consisting of one representative each from three groups of countries: western, socialist and neutralist. The harsh Soviet attack on the office of the Secretary-General did not find any supporters, as would become apparent during subsequent deliberations in February 1961.

By November 1960, ONUC had become a military target for some factions. ${ }^{74}$ Towards the end of the month, an incident took place which added to the controversy about the UN presence: Lumumba and two other senior politicians were detained while under ONUC protection. ${ }^{75}$ Shortly after Lumumba's arrest, his intellectual heir, Antoine Gizenga, ${ }^{76}$ proclaimed the reestablishment of the 'legal government of the Republic of the Congo' in a new capital, Stanleyville. ${ }^{77}$

\section{Transition in authority}

During the Security Council meeting of 7-14 December 1960, the Soviet Union and the Afro-Asian group demanded direct UN action to release Lumumba and to disarm Mobutu's ANC. The Soviet bloc and several nonaligned members were calling for UN action against the Central Government - a measure opposed by Hammarskjöld on the grounds that such use of force would constitute an internal intervention unauthorised by existing UN resolutions. Unless the Security Council expressly invoked Chapter VII for enforcement purposes, he argued, the safeguards against intervention in 
Article 2.7 could not be suspended. ${ }^{78}$ A draft resolution sponsored by Argentina, Britain, Italy, and the United States, which merely emphasised the rights of arrested persons, was vetoed by the Soviet Union, while a Polish draft, which would have requested the Secretary-General to undertake the necessary measures to obtain Lumumba's immediate release, was rejected by 6 to 3 , with 2 abstentions.

During the General Assembly meeting two days later, two principal views emerged as to how the UN should now proceed. On one side was the AngloAmerican draft requesting the Secretary-General to assist President Kasavubu in establishing favourable conditions for the Parliament to function. This draft also expressed the hope that the roundtable conference being called by Kasavubu and the pending visit to the Congo by the UN Conciliation Commission would help to resolve internal conflicts by peaceful means. ${ }^{79}$ The language of this draft, which conferred legitimacy on the military regime backed by Kasavubu, was consistent with the US position which gave pride of place to the principle of non-intervention:

As for the status of Mr. Lumumba in the political system of the Republic of the Congo ... [i]t is a problem of internal Congolese jurisdiction and not one for the Security Council or the General Assembly to judge; it is not for the Security Council or the General Assembly to choose between sides in an internal conflict and interfere in the internal affairs of a sovereign Member State. ${ }^{80}$

On the other side, an eight-member ${ }^{81}$ draft resolution urged the immediate release of all political prisoners; the immediate convening of Parliament; and measures to prevent 'armed units from interfering in the political life of the Congo'. This draft, which in essence questioned the whole legitimacy of the Kasavubu-Mobutu regime, called on the UN to take the initiative in restoring the rightful government of the Congo. The Congolese people had given clear support to Lumumba, and the military regime, installed by imperialist powers, could not be recognised as legitimate. Neither resolution was adopted. ${ }^{82}$ No consensus emerged as to what exactly the UN should do in response to the crisis. There was, nevertheless, growing pressure against the position taken by the West.

Interestingly, Kasavubu, who was supported by the United States, was also calling for more active UN intervention, though for a completely different reason. Following Lumumba's arrest and rumours that he had been tortured and killed, Stanleyville had substantially transformed its campaign into a military one. Kasavubu threatened that if the UN did not stop these attacks, he would seek outside assistance..$^{83} \mathrm{He}$ had already made an attempt to take over the Kitona base from ONUC. Rajeshwar Dayal, Bunche's Indian successor, however, with the Katanga precedent in mind, replied that ONUC could not intervene in a dispute between a central and a provincial government. ${ }^{84}$ 
On 3-7 January 1961, six Third World countries, contributing troops to ONUC, attended a conference at the level of heads of state in Casablanca. ${ }^{85}$ They adopted a declaration, which demanded that Mobutu's soldiers be disarmed, Lumumba and his friends be freed, the Parliament be re-convened, all Belgian military and paramilitary personnel be removed, and all airports and other establishments be returned to the 'legitimate' government of the Congo. These countries further reaffirmed their intention to withdraw from ONUC, should the UN not respond to their demands. The UN was now explicitly invited to play a defining role in the 'domestic' affairs of a member state, since it was called upon to convene a dysfunctional parliament and to reinstall a 'legitimate' government.

\section{Security Council paves the way: SC Resolution 161}

Upon the announcement of Lumumba's killing, the Security Council held a meeting on 15-21 February, which resulted in SC Resolution 161 of 21 February 1961. Drafted by Ceylon, Liberia and the UAR, the Resolution was adopted by 9 votes to 0 , with the Soviet Union and France abstaining. ${ }^{86}$ The resolution was radically different from the previous resolutions in two important respects. First, it put the main emphasis on the internal dimension of the crisis. Secondly, the resolution outlined how the UN had to respond to the latest developments in the theatre of conflict, whereas the choice of operational targets had in previous resolutions been left largely to the Secretary-General. The reason for this shift was not only the dissatisfaction of some member states with the Secretary-General, but also Hammarskjöld's belief that specific endorsement by the Security Council of prescribed methods of action, involving especially the use of force, would eliminate attacks on his interpretation of ONUC's mandate. ${ }^{87}$

At the beginning of the session Hammarskjöld gave his reply to the Soviet Union, which had held him personally responsible for Lumumba's death, demanded his dismissal from the post of the Secretary-General, and called for an end to ONUC within one month. ${ }^{88}$ This time Hammarskjöld, referring to Khrushchev's 'troika' proposal, accused the Soviet Union of trying to change the structure of the UN to increase its own influence. He vigorously defended his interpretation of ONUC's mandate, arguing that he came under attack because the UN had not exceeded its mandate. He insisted that the UN 'had neither the power nor the right' to liberate Lumumba from captivity. 'I say the UN,' he continued, 'because to my knowledge not even this Council or the General Assembly would have such a right, much less did it exist for the UN representatives in the Congo.'

Soviet criticisms of Hammarskjöld were not widely shared by other actors. India, for instance, rejected the Soviet invitation to support its position on the Congo, declaring instead its confidence in the Congo operation and in the 
Secretary-General. In March, India would contribute a brigade to ONUC. ${ }^{89}$ This support was important in that it came from a respected member of the Afro-Asian group and a leading non-aligned country, which had not been at all uncritical of the UN's Congo policy. ${ }^{90}$

Notwithstanding his defence, Hammarskjöld was aware that expectations of ONUC had changed since the outset of the operation. In response to growing Soviet and Third World demands, he proposed a more assertive line of action for ONUC: Lumumba's death should be investigated; civilians should be protected regardless of their background; ${ }^{91}$ all means short of force should be used to stop clashes, including the establishment of neutral zones and cease-fire agreements; the ANC should be withdrawn from politics; the Belgian political as well as military elements should be removed from the Congo. The Secretary-General went on to propose that the Parliament be reconvened, capital movements be controlled, and means of transportation be inspected to prevent supply of arms. Hammarskjöld, acting through his representatives, had previously opposed the disarming of the ANC on the grounds that this required the Government's consent. He had, in other words, appealed to a stricter interpretation of 'sovereign rights'. As events unfolded, his concern over the maintenance of peace and security would take precedence over strict respect for sovereignty.

Hammarskjöld's recommendations, taken together with the decision to create a Conciliation Commission, point to a crucial notion, which would assume increasing importance for the UN's peacekeeping agenda, namely national (re)conciliation. During the Congo episode, the UN gradually began to define its role as a comprehensive conciliator. A growing number of states endorsed, implicitly or explicitly, an unprecedented role for the UN, that is, creating, within a 'sovereign' state, the conditions for a relatively coherent and harmonious society. This idea would be explored, systematised, and applied with greater sophistication in the 1990s peacekeeping missions, not least those in Angola and Cambodia.

Another idea that would be more systematically examined in the 1990s was temporary UN administration in war-torn societies. Pakistan, for instance, recommended to the Security Council during the February discussions that the UN administer the Congo as a trust territory until such time as 'the Congolese people may be enabled to achieve their own political settlement'. Similarly, an independent, non-official American study found that the UN was now dealing with a problem which in the past had been solved by a trusteeship arrangement or some other form of external administration. ${ }^{92}$ But given the opposition to colonialism and the strong Third World insistence on 'independence', Congolese leaders and the majority of the UN membership did not embrace the idea.

By Resolution 161, the Security Council for the first time expressed 
concern over 'the danger of a widespread civil war and bloodshed in the Congo'. Part A of the resolution authorised ONUC to take 'all appropriate measures to prevent occurrence of civil war in the Congo'. The Security Council, no longer able to ignore the internal tensions in the Congo, made prevention of civil war the main mandate for ONUC. The whole preamble and the first operative paragraph of Part A were devoted to the issue of civil war. ${ }^{93}$

Resolution 161 defined the following functions for ONUC: arrangements for a cease-fire; halting of all military operations; prevention of clashes (these three functions were prescribed by the Security Council in relation to the possibility of a widespread civil war, and were complemented by the authorisation of 'use of force, if necessary, in the last resort'); evacuation of all non-UN foreign personnel from the country; immediate and impartial investigation of Lumumba's killing; punishment of Lumumba's murderers; ${ }^{94}$ protective measures to enable the reconvening of the Congolese Parliament; and arrangements to ensure that Congolese armed units and personnel were reorganised and brought under control. ${ }^{95}$

In contrast to the previous resolutions, Resolution 161 referred only to 'the Congo' instead of 'the Government' or 'the Republic' of the Congo. The whole of Part B of the Resolution highlighted 'the imperative necessity of the restoration of the parliamentary institutions in the Congo'. The purpose was to bring the parties, which were in a formal sense equally respected, to the negotiation table. However, neither Kasavubu nor Gizenga was pleased with the new role and methods that the Security Council had prescribed for ONUC, which had significantly departed from the original mandate.

With the authorisation of the use of force, the Security Council's adherence to the norm of non-use of force was now open to question. A shift had occurred from Hammarskjöld's notion of peacekeeping towards that of peace enforcement, as originally demanded by the Soviet Union. Resolution 161, like the previous resolutions, was not adopted under Articles 41 or $42 .{ }^{96}$ Despite fears that international peace and security would be endangered by a civil war in the Congo, the situation was not formally perceived to be sufficiently threatening to warrant an active enforcement mandate. Nevertheless, with the authorisation of the use of force for purposes other than self-defence, the Security Council's response had turned ONUC into a 'Chapter six and three-quarters' operation, giving it greater authority than originally envisaged.

It is worth noting that Resolution 161 could have been vetoed by Britain, had Hammarskjöld not reassured the Security Council that the new authority did not extend to any objective other than the prevention of civil war. The resolution could not be used, in his opinion, to impose any political solution on the parties. It did not even give ONUC the right to search incoming trains or planes for mercenaries or weapons. ${ }^{97}$ 
General Assembly endorses

Changes to ONUC's normative basis were driven not only by the Security Council, but also by the General Assembly. On 21 March 1961, the Conciliation Commission ${ }^{98}$ published its report and recommended the following: ${ }^{99}$ redrafting of the 'incomplete and ill-adapted' Loi fondamentale 'especially in the direction of greater decentralisation'; reconvening of the Parliament under UN protection; reorganisation of the ANC in isolation from politics; and convening of a summit meeting of African leaders. The Commission further expressed its opinion that only a federal form of government could preserve the national unity and integrity of the Congo.

The Commission's recommendations all related to the domestic affairs of the host country, and suggested that the envisaged role for the UN in the Congo clearly went beyond promotion of 'external' sovereignty. Slowly, an anomalous normative position, indeed a normative dilemma, was emerging, which would not fully crystallise until the 1990s: the UN was now expected to promote 'internal' sovereignty (i.e. create an effectively functioning government that enjoyed a reasonable degree of legitimacy) by casting aside respect for 'external' sovereignty (i.e. by violating the principle that it could not tell a government what to do in its domestic affairs).

Despite heavy criticism by Kasavubu on the one hand and Tshombé on the other, ${ }^{100}$ the General Assembly adopted on 15 April 1961 three resolutions which gave clear support to SC Resolution 161. The first explicitly stated that the central factor in the grave situation in the Congo was the continued presence of foreign military personnel, political advisors and mercenaries. ${ }^{101}$ The second provided for 'national reconciliation and a return to constitutionality', ${ }^{102}$ acknowledging the illegality and unconstitutionality of the KasavubuMobutu-Ileo regime. ${ }^{103}$ The third appointed the members of the commission of investigation into Lumumba's killing set up by the Security Council. ${ }^{104}$ These resolutions reflected largely the concerns of the Casablanca group about developments in the Congo. The General Assembly's formulation was more in line with the overall Soviet view than the western view in that issue was taken with the UN policy of 'non-intervention'. Moreover, the notion that the UN had a role to play in the process of 'national (re)conciliation' became firmly established. The tendency in the General Assembly was towards a more assertive UN role in the Congo. However, the resolutions were not adopted by wide margins, with a significant level of opposition registered for each of the three resolutions, as indicated by the large number of negative votes and abstentions.

ONUC did not implement the February resolution until September 1961. In late March, when the Katangese gendarmerie occupied the positions of the Nigerian contingent, ONUC did little beyond reiterating that it was entitled to oppose and resist such a move. ${ }^{105}$ Between April and August, UN representatives in Katanga repeatedly tried, without success, to convince the provincial 
authorities that the February resolution would be implemented. It was only after the establishment of the Adoula Government that ONUC would eventually resort to force. ${ }^{106}$ Despite the push by the Casablanca powers, one reason for ONUC's hesitation to resort to coercion was the concerns of another group of African states led by Cameroon, Liberia, Nigeria and Togo, which held a meeting in Monrovia on 8-12 May 1961. The 'Monrovia group' would soon include 22 African countries. These states were more moderate in their approach towards the Congo. In general, their insistence on pan-Africanism was not as 'enthusiastic' as that of the Casablanca group. ${ }^{107}$

On 22 July 1961, the Congolese Parliament reconvened. Most members of parliament were brought to Léopoldville under ONUC's protection. On 2 August, a Government of National Unity was constituted by Cyrille Adoula at Kasavubu's request. The Constitutional Crisis, at least on paper, had come to an end. On 7 August, Gizenga himself recognised the Adoula Government as the sole legal government of the Republic and was simultaneously appointed deputy prime minister. ${ }^{108}$ In mid-September, ONUC proceeded to round up the mercenaries for deportation. ${ }^{109}$ The unexpected resistance turned the operation into a military action. The optimistic atmosphere rapidly changed as hostilities against UN personnel increased. ${ }^{110}$ On 17 September 1961, Hammarskjöld died in a plane crash on his way to meet Tshombé. ${ }^{111}$

\section{SC Resolution 169: forceful protection of sovereignty}

Escalation of violence led to another Security Council meeting. Ceylon, Liberia and the UAR submitted a draft resolution, ${ }^{112}$ which included the following operative paragraphs:

The Security Council,

2. Further deprecates the armed action against United Nations forces and personnel in the pursuit of such activities; ...

11. Requests all Member States to refrain from any action which may directly or indirectly impede the policies and purposes of the United Nations in the Congo and is contrary to its decisions and the general purposes of the Charter.

The United States proposed the following amendments to the above paragraphs: ${ }^{113}$

The Security Council,

2. Further deprecates all armed action against United Nations forces and personnel and against the Government of the Republic of the Congo; ...

11. Requests the Secretary-General to assist the Government of the Republic of the Congo to re-organize and retain Congolese armed units and personnel to assist the Government to develop its armed forces for the tasks which confront it.

Both amendments attempted to establish a closer relationship between the Central Government and the UN, and their wording was in conformity with 
the previous SC Resolutions. These amendments were vetoed by the Soviet Union which was no longer willing to encourage active UN support for the new Central Government. Nonetheless, the ninth operative paragraph, building on the precedent set by SC Resolution 145, would make it clear that the Security Council was determined to assist the Central Government to maintain law and order and national integrity.

On 24 November 1961, after ten days of intense discussions, the original three-power draft was adopted as SC Resolution 169 by 9 votes to 0, with Britain and France abstaining. ONUC's mandate changed once again. The primary task was not to put an end to external interference or prevent civil war. Instead, it was to suppress secessionist activities, especially those in Katanga. ${ }^{114}$ By this resolution, the Security Council 'completely rejected the claim that Katanga was a sovereign independent nation' ${ }^{115}$ The first operative paragraph deprecated 'the secessionist activities illegally carried out by the provincial administration of Katanga'. The eighth operative paragraph declared that 'all secessionist activities against the Republic of the Congo were contrary to the Loi fondamentale and Security Council decisions' and specifically demanded 'that such activities which were taking place in Katanga should cease forthwith'.

Like the previous resolutions, SC Resolution 169 intended to restore 'law and order' in the Congo, and to remove any impediments to the Government's exercise of its authority. While the overall wording of the earlier resolutions was retained, much had changed in terms of the underlying perceptions. The Katanga question was now considered an 'internal' question, as reflected in the formulations of Resolution 169. Whereas Resolution 146 had called upon 'the Government of Belgium to withdraw immediately its troops from the Province of Katanga', ${ }^{116}$ Resolution 169 referred to 'secessionist activities and armed action being carried on by the Provincial Administration of Katanga with the aid of external resources and foreign mercenaries' ${ }^{117}$ The perceived parties to the problem had changed. Now Katanga rather than Belgium was seen as the relevant party to the dispute. More to the point, while the UN had carefully avoided 'intervention' in matters between the central and provincial governments at the initial stages of the mission, it was now expected to intervene.

In Resolution 169, the requirement of consent was reserved for the Central Government. As a result of the lengthy discussions over the space of one and a half years, protection of the Congo's sovereignty, by which was meant ensuring its territorial integrity and unity, eventually emerged as ONUC's dominant normative objective alongside maintenance of international peace and security. The Security Council did pronounce its verdict as to what should be the political solution: Katanga simply had to continue to be part of the Republic of the Congo. 
With Resolution 169, the Security Council further authorised ONUC to 'take vigorous action, including the use of requisite measure of force, if necessary, for the immediate apprehension' of all non-UN foreign personnel. The United States demanded that ONUC be given the authority to render useless hostile war machines such as aircraft, and to prevent their use against ONUC or civilians. The United States also wanted the UN to mediate in the internal political conflict, thus making it possible for other secessionist challenges to be taken into account. Unable to resist the ever-growing Second and Third World pressure to suppress Katanga's secession attempt, the United States tried to make the most of the anti-secessionist sentiment and drew attention to the 'secessionist' Stanleyville movement led by pro-Soviet Gizenga. By November 1961, both the Soviet Union and the United States were supporting moves to end the secession problem. ${ }^{118}$

Following the termination of ONUC, the US Assistant Secretary of State for African Affairs identified six key factors underlying US opposition to an independent Katanga. ${ }^{119}$ First, under Belgian rule, Katanga had always been an integral part of the Congo - a judgement clearly accepted by the Brussels Round Table Conference of 1960. Second, secession would disrupt the Congo's economic fabric and destroy its potential for economic viability. Third, though Tshombé was anti-communist, there were other moderate Congolese leaders of the same quality. Fourth, if Katanga were allowed to secede, other regions might follow it, resulting in a chaotic situation which would invite communist penetration. Fifth, if the problem of Katangan secession were solved, it would strengthen Léopoldville's capacity to cope with communist Gizenga. And sixth, to enhance America's stature in the eyes of the emerging nations, Washington had to oppose Tshombé's attempted secession which most Afro-Asians believed to be a product of western neo-colonialism.

The last three factors offer perhaps a more plausible explanation for the US attitude towards Katanga, which shifted from 'toleration' to 'opposition'. The first three were present all along. As the crisis unfolded, potential ramifications of Katanga's secession became clearer. Furthermore, the sensitivity of the newly born states to the issue of sovereignty, with particular emphasis on territorial integrity and political independence, became ever more visible as indicated in General Assembly discussions. As a consequence, the United States re-evaluated its position and adopted an anti-Katanga policy at the expense of its allies Belgium, Britain and France.

Britain continued to oppose ONUC's involvement in internal political problems on the grounds that such a 'military solution' would create a 'very dangerous precedent' for any state seeking to suppress a dissident faction. ${ }^{120}$ A month later, the British Foreign Secretary would argue that the UN might 'sow the seeds of its own destruction' if it neglected its primary duty, that is 
maintenance of peace and security, and turned instead to 'the acceleration of independence and the eradication of colonialism, which is a subsidiary issue'. ${ }^{121}$ Britain abstained from the Resolution. France abstained on similar grounds: '. . . no doubt that the use of force could bring nothing but results contrary to that which is sought by the Council'. ${ }^{122}$

The authority assigned to ONUC did not change after the adoption of SC Resolution 169. In December 1961 fighting broke out between ONUC personnel and Katangan forces. ONUC's success led to the signing of the Kitona Declaration, which was the first concrete step towards ending Katanga's secession. In August 1962, U Thant, Hammarskjöld's successor, proposed a 'Plan of National Reconciliation' which took the idea of a Conciliation Commission one step further. In this plan he set out the details of a possible arrangement between the Central Government and the Provincial Government, designed to resolve the secession problem once and for all. ${ }^{123}$

In September 1962, U Thant finally ensured the acceptance of the plan by both Adoula and Tshombé. On 11 December, Katanga having demonstrated its unwillingness to implement his plan, U Thant requested member states to impose economic sanctions on the Province, in particular by stopping its export of copper and cobalt. On 28 December another round of clashes took place between ONUC and Katanga. ${ }^{124}$ Following ONUC's military success, Katangan authorities sent a message to U Thant, agreeing to end the secession. ${ }^{125}$ On 17 January 1963, Tshombé signed a document and undertook to facilitate the peaceful entry of ONUC into Kolwezi. The secession of Katanga had formally ended. At Adoula's request, a small UN force of about 3,000 men remained in the Congo through the first half of 1964. On 30 June 1964, ONUC withdrew completely.

\section{Concluding observations}

The Congo crisis and the UN's response to it developed in the geopolitical context of the North-South and East-West conflicts. Two competing normative attitudes, reflecting two different sets of interests, defined the UN's objectives and authority. While the (neo)colonial powers strongly favoured the newly born 'peacekeeping' doctrine, the socialist bloc pressed for what might be loosely referred to as collective security action against 'external' threats to the Congo's sovereignty. The socialist position revolved around two distinct but closely related political goals: gaining support among newly independent Third World countries which opposed colonialism, and weakening the western foothold in Africa.

The United States, under pressure from the anti-colonialist and nonaligned South, played a key role in bridging these diverse interests and normative preferences. The US political attitude underwent significant 
change in the course of the mission, and heavily impacted on the emergence of 'dominant' normative views at critical moments of the crisis, particularly with respect to ONUC's authority in the handling of the conflict. At first, the United States favoured the Hammarskjöld formula, in line with (neo)colonial interests. However, as time passed, it redefined its priorities in the face of the mounting threat of unilateral Soviet intervention in the Congo and growing dissatisfaction among non-aligned states in general, and Afro-Arab states in particular. It now applied more and more pressure on its (neo)colonial allies and on the UN with a view to 'appeasing' the Soviet bloc and the Third World. As a consequence, ONUC's authority expanded and Katanga's attempt at secession was eventually defeated. The one constant in an otherwise fluctuating US position was the determination not to let the Soviet Union score a victory in the global contest for power and influence.

ONUC's authority was redefined in all its four dimensions. The requirement of consent by all parties was eventually abandoned. The UN was called upon to pass judgement on the rights and wrongs of the conflict, set aside strict adherence to neutrality, declare the secessionist attempts illegitimate, and eventually have these decisions implemented by ONUC. Force was used to suppress Katanga's secession: that is, for purposes other than self-defence. The increase in the UN's authority was also evident in the expansion of its functions. When, after Lumumba's death, 'civil war' became a critical issue, the UN developed a step-by-step plan for 'national conciliation'. Hammarskjöld's Afro-Asian Conciliation Commission, which was endorsed by the General Assembly, and U Thant's Plan of National Reconciliation were important milestones in the embryonic development of the UN's national (re)conciliation agenda, which we shall have occasion to revisit in the context of the Angola and Cambodia case studies. Both Secretaries-General, their non-intervention rhetoric notwithstanding, contributed to the UN's increasing authority vis-àvis the Congo. Perhaps more importantly, ever deeper UN involvement in the Congo's internal affairs was encouraged both by the Security Council and the General Assembly in their collective capacity.

The change in authority, however, did not entail a change in objectives. Maintenance of international peace and security was the main preoccupation of the international community throughout the ONUC episode - even when ONUC was required to maintain domestic law and order. While international actors remained largely silent on human rights during the Congo operation, the principle of state sovereignty, perceived in its 'external' dimension and with the emphasis very much on territorial integrity and political independence, informed international normative expectations of the UN. Yet the manifestations of this concern were strikingly diverse.

So far as the colonial powers were concerned, the main import of the sovereignty principle was that the UN had no right to address the Congo's 
internal affairs, including the problem of secession. For the socialist bloc and a large group of non-aligned states, on the other hand, the UN was required to 'intervene' (that is, both to deploy forces and to address the so-called domestic issues) precisely because protection of state sovereignty was one of the UN's main responsibilities. The United States, in an effort to accommodate these conflicting positions, did not itself adopt a clear stance on these questions, preferring to advance its interests by adapting to the changing international environment, in which anti-colonialist and anti-secessionist sentiment in the Third World now exerted a substantial influence.

In normative terms, the 'resolution' that emerged in the context of the Congo operation was more a spontaneous synthesis than a lasting resolution or reconciliation. The positions adopted by virtually all relevant actors pointed to contradictory interests and value preferences. What they were arguing for, normatively speaking, was not clear. In some cases ambiguity and contradiction described the twists and turns of policy on the part of individual actors. More fundamentally, however, these tensions had a structural underpinning. They were all shaped in close interaction with each other. Taken in isolation they lost their meaning. Taken together, on the other hand, they suggested that the double peaks of the East-West and North-South conflicts had given rise to a particularly tense international environment, in which any resolution of competing norms and interests would be at best partial and provisional.

\section{NOTES}

1 Derived from the initials of its full name in French: Organisation des Nations Unies au Congo.

2 E. W. Lefever, Uncertain Mandate: Politics of the U.N. Congo Operation (Baltimore, MD: The Johns Hopkins Press, 1967), p. 3.

3 The estimated population of the Congo in 1960 was 15,310,000: see United Nations, World Population Prospects 1990 (New York: UN Population Studies No. 120, 1991), p. 602. The ratio of ONUC's strength to the local population was 13/10,000.

4 Exact figures cited in United Nations, The Blue Helmets: A Review of United Nations Peace-keeping, 2nd edn (New York: UNDPI, 1990), p. 435.

5 King Léopold II colonised the Congo in competition with other colonialist powers, in particular Britain. Eventually Léopold's ownership of the Congo was endorsed in the Berlin Conference of 1885.

6 Katanga was rich in copper and cobalt, and had been the principal supplier during World War II of uranium for the US atomic bomb programme. Kasai, on the other hand, produced 80 per cent of the world's industrial diamonds. By 1960, the former province was generating 80 per cent of the Congo's export revenues and half of its total income.

7 Union Minière and its partners dominated practically every aspect of administration in Katanga and its vicinity. Forminière, a subsidiary of Union Minière, was in control of substantial mines near Bakwanga in South Kasai: see J. K. Gordon, The United Nations in the Congo: A Quest for Peace (New York: Carnegie Endowment for International 


\section{The UN, intra-state peacekeeping and normative change}

Peace, 1962), p. 52. For a survey of US and British business interests in the Congo in general, and in Katanga in particular, see D. N. Gibbs, The Political Economy of Third World Intervention: Mines, Money, and U.S. Policy in the Congo Crisis (Chicago, IL: The University of Chicago Press, 1991).

8 In January 1959, a major riot broke out in Léopoldville (Léopoldville was the name of both the Congolese capital, that is, today's Kinshasa, and the western province in which the capital was located).

9 In March 1960, an 'Executive College' of six Congolese political leaders was formed to serve as a transitional regime and to draft a constitution. This provisional government was led by Belgian Governor-General Henry Conelis: see Kanza, Conflict in the Congo, p. 177.

10 The Congolese MPs came from 24 different parties. The strongest party won 41 seats, whereas none of the others could go beyond 15. The 22 ministers of the emerging Congolese Government represented 12 different parties: see S. R. Weissman, American Foreign Policy in the Congo 1960-1964 (Ithaca: Cornell University Press, 1974), p. 19; and C. Young, Politics in the Congo: Decolonization and Independence (Princeton, NJ: Princeton University Press, 1965), p. 302.

11 Kasavubu was the leader of Alliance des Bakongo (ABAKO), the political organisation of the Bakongo peoples. Established in 1950 (i.e. the oldest political organisation represented in the Parliament), ABAKO was particularly powerful in the western Province of Léopoldville: see Young, Politics in the Congo, p. 304; Gibbs, The Political Economy of Third World Intervention, p. 74.

12 Lumumba, the leader of Mouvement National Congolais (MNC), was of Mutetela ethnic origin. He was certainly a nationalist and allegedly a communist, and aroused considerable antipathy in the West. Established in October 1958, his party quickly ensured significant popular support. Gaining 41 seats in the parliament, MNC appeared as the most successful party in the elections. The stronghold of the party was Stanleyville: see, in general, Gibbs, The Political Economy of Third World Intervention; and Weissman, American Foreign Policy, p. 18.

13 Moise Tshombé was the leader of the Confederation des Associations Tribales du Katanga (CONAKAT). Established in October 1958, CONAKAT was the voice of the Lunda and Bayeke peoples in Katanga. Yet it was dominated by the white community, by Union Minière: see Young, Politics in the Congo, p. 304; Gibbs, The Political Economy of Third World Intervention, p. 85.

14 SC Resolution 143 of 14 July 1960 was adopted by 8 votes to 0, with three abstentions. The United States and the Soviet Union were the only two permanent members of the Security Council to vote in favour. The next day the first party of the UN Force (90 Tunisian officers and soldiers) landed at Léopoldville, followed by the remainder in the next few days. ONUC was initially welcomed by the local population as saviours from the Belgians: see L. P. Bloomfield, 'Political control of international forces in dealing with problems of local instability', in A. J. Waskow (ed.), Quis Custodiet? Controlling The Police in a Disarmed World (Washington, DC: Peace Research Institute, 1963), p. E-4.

15 The two telegrams by Kasavubu and Lumumba on 12 and 13 July 1960 (reproduced in S/4382 of 13 July 1960), which initiated the resolution process in the Security Council, clearly underlined that their demand was related to the Belgian 'aggression', and not to the restoration of the internal situation in the Congo. Prior to these official requests, several oral requests had been directed by individual Congolese leaders to the $\mathrm{UN}$ as well as to major powers.

16 Weissman, American Foreign Policy, p. 62. 


\section{The UN in the Congo conflict}

17 The Republic of the Congo had been recommended for UN membership by an SC resolution on 7 July 1960 as a country made up of 6 provinces, one of which was Katanga: see Gordon, The United Nations in the Congo, p. 19. Formally, the Congo became a UN member on 20 September 1960 , that is, more than two months after the adoption of SC Resolution 143.

18 See G. Abi-Saab, The United Nations Operation in the Congo 1960-1964 (Oxford: Oxford University Press, 1978).

19 Weissman, American Foreign Policy, p. 63.

20 L. B. Ekpebu, Zaire and The African Revolution (Ibadan, Nigeria: Ibadan University Press, 1989), p. 55.

21 The first sought to 'condemn the armed aggression by Belgium'. The second required 'immediate' Belgian withdrawal. And the third demanded that all UN troops be supplied by African members: Ekpebu, Zaire and The African Revolution, p. 131.

22 I. J. Rikhye, 'Hammarskjöld and peacekeeping', in R. S. Jordan (ed.), Dag Hammarskjöld Revisited: The UN Secretary-General as a Force in World Politics (Durham, NC: Carolina Academic Press, 1983), p. 95.

23 T. M. Franck and J. Carey, 'Working paper: the role of the United Nations in the Congo - a retrospective perspective', in L. Tondel Jr. (ed.), The Legal Aspects of the United Nations Action in the Congo (New York: Oceana Publications, 1963), p. 16.

24 S/PV.873 of 13/14 July 1960.

25 The Soviet affirmative vote to ONUC's authorisation - despite the mandate's failure to refer explicitly to what the Soviet Union perceived to be aggression - reflected an understanding which did not clearly distinguish between 'peacekeeping' and 'peace enforcement'.

26 SC Resolution 145 dated 22 July 1960.

27 The essence of Resolution 143 was encapsulated in the first operative paragraph of Resolution 145, which repeated the previous call upon Belgium for withdrawal of their troops and authorised the Secretary-General to take all necessary action to this effect. The fourth operative paragraph was addressed to the specialised agencies of the wider UN system, which were hereby invited to render to the Secretary-General such assistance as he might require.

28 Sir Roy Welensky, Prime Minister of Rhodesia, reportedly told a British journalist just before independence that 'a vast and rich part of the Belgian Congo that will become independent on July 1 could throw off its old ties and join the Federation': see Gordon, The United Nations in the Congo, p. 34. Welensky remained a strong supporter of Katanga. When the British attitude changed in response to American pressure in the later stages of ONUC, Britain would expend enormous effort to change Welensky's mind: see A. James, Britain and the Congo Crisis, 1960-63 (Houndmills: Macmillan, 1996), pp. 138, 142.

29 The fifth preambular paragraph reflected this conception of law and order, and maintained that the complete restoration of law and order in the Republic of the Congo would effectively contribute to the maintenance of international peace and security'.

30 Throughout the crisis Britain would strongly advocate the idea that 'the UN force should keep itself detached from the internal politics of the Congo'; see James, Britain and the Congo Crisis, p. 78.

31 In August, Belgian troops withdrew from the Congo with the exception of their two military bases in Kitona and Kamina.

32 The total estimated strengths of Katanga's gendarmerie and the Government's ANC (Armee Nationale Congolaise; formerly known as the Force Publique during the 


\section{The UN, intra-state peacekeeping and normative change}

colonial administration) were 18,026 and 24,300 respectively: see T. S. Soo, The Malayan Special Force in the Heart of Africa (Malaysia: Palanduk Publications, 1989), Appendices I and II.

33 From one perspective, the mercenary problem was simply the continuation of the Belgian intervention. Indeed, there were clear links between the two problems. From another perspective, however, the mercenary problem added a different logic to the development of the crisis. First, the mercenaries in Katanga came not only from Belgium, but also from countries as diverse as South Africa and Poland (see, for instance, Ekpebu, Zaire and The African Revolution, p. 110). Secondly, not all Belgian mercenaries were ex-officers of the Belgian army. There were also a significant number of volunteers. Although the UN did manage to deal effectively with the problem of direct Belgian intervention, the mercenary problem continued up until the end of ONUC, and even beyond.

34 See, Kanza, Conflict in the Congo, pp. 100-1.

35 The so-called 'Mining State' or 'Diamond State' covered approximately one-third of the Kasai Province. Although Kasai's attempt resembled the Katanga secession in that it involved vested foreign economic interests, the Kasai case had more significant tribal roots. Kalonji's Baluba movement was a reaction to the continued Lulua actions against the Baluba in Kasai.

36 For the detailed exchanges between Hammarskjöld, Tshombé, Bunche and Belgian authorities, see S/4417 of 6 August 1960.

37 Gordon, The United Nations in the Congo, p. 38.

38 Gordon, The United Nations in the Congo, p. 32.

39 The wording of the preambular paragraphs in particular reveals that the diagnosis of the previous two resolutions was essentially retained. SC Resolution 146 identified the problem as the continuing Belgian presence in one part of the Congo. The issue at stake was still considered to be external interference rather than internal unrest. This conclusion is corroborated by the second and third operative paragraphs. Accordingly, the Belgian intervention in the Congo was now confined to Katanga which was a province of the unitary Republic of the Congo.

40 Operative para. 4.

41 Gordon, The United Nations in the Congo, p. 39.

42 See S/PV 885 of 8 August 1960, pp. 58-60.

43 Franck and Carey, 'Working paper', p. 19.

44 Lefever, Uncertain Mandate, p. 114.

45 See, for instance, the Soviet statement in S/PV.920 of 13 December 1960, p. 11.

46 He was mainly referring to the Lebanon crisis of 1958: see S/4417/Add.6 of 6 August 1960, para. 2.

47 The Congolese constitution (Loi fondamentale).

48 S/4417/Add. 6 of 6 August 1960, para. 6.

49 See Gordon, The United Nations in the Congo, p. 45.

50 The Soviet Bloc and African nationalist states grew increasingly sceptical of Hammarskjöld's 'impartiality'. First Bunche and then Hammarskjöld himself had entered Katanga by permission of Katangan authorities. Hammarskjöld even found himself in a position where he had to listen to the Katangese 'national anthem'. Impartiality had gone too far; it was now working to the detriment of the Congo's sovereignty.

51 Hammarskjöld would argue the exact opposite in his Introduction to the Sixteenth Annual Report of 17 August 1961: 'It is a thankless and easily misunderstood role for the Organization to remain neutral in relation to a situation of domestic conflict and to 


\section{The UN in the Congo conflict}

provide active assistance only by protecting the rights and possibilities of the people to find their own way, but it remains the only manner in which the Organization can serve its proclaimed purpose of furthering the full independence of the people in the true and unqualified sense of the word': GAOR, 16th Session, Supl No.1A (A/4800/Add.1).

52 See C. Hoskyns, The Congo Since Independence: January 1960-December 1961 (London: Oxford University Press, 1965), pp. 176-7.

53 M. G. Kalb, The Congo Cables: The Cold War in Africa - From Eisenhower to Kennedy (New York: Macmillan, 1982), p. 48.

54 Congolese soldiers began to harass UN personnel: see, for instance, Kalb, The Congo Cables, pp. 52-3. By the end of the month, the reform programme for the ANC, which had been initiated at Lumumba's request, would be interrupted: see Gordon, The United Nations in the Congo, pp. 49-50.

55 Rikhye, The Theory and Practice of Peacekeeping, p. 83.

56 These measures were taken on the initiative of the acting Special Representative, Andrew Cordier, another US citizen. For an analysis of Cordier's role in the crisis, see C. J. L. Collins, 'The Cold War comes to Africa: Cordier and the 1960 Congo crisis', Journal of International Affairs, 47:1 (Summer 1993), 243-69.

57 Kasavubu had no such need anyway. Even if he had, the facilities in the neighbouring French Congo would be made available to him: see, for instance, James, Britain and the Congo Crisis, pp. 70-1.

58 Franck and Carey, 'Working paper', p. 22.

59 After the Congo Crisis, on 23 November 1965, Mobutu would conduct a second coup and become the dictator of 'Zaire'.

60 The Collège was to be drawn from the university students and graduates, whose number was extremely small.

$61 \mathrm{~S} / 4523$ of 16 September 1960.

$62 \mathrm{~S} / 4526$ of 17 September 1960.

63 Ceylon, Ethiopia, Ghana, Guinea, Indonesia, Iraq, Jordan, Lebanon, Liberia, Libya, Morocco, Nepal, Saudi Arabia, Sudan, Tunisia, the UAR, and Yemen.

64 Operative para. 2.

65 Operative para. 6.

66 Operative para. 3.

67 Gordon, The United Nations in the Congo, p. 61.

68 Lefever, Uncertain Mandate, p. 116.

69 These included Castro, Eisenhower, Khrushchev, Macmillan, Nasser, Nehru, Nkrumah, Sukarno, Tito and Touré.

70 Ceylon, Ghana, India, Indonesia, Mali, Morocco, and the UAR.

71 On 20 November 1960 by 53 votes to 24, with 19 states abstaining.

72 For example, Canada and Sweden.

73 GAOR, 15th Session, 869th Plenary Meeting.

74 On 8 November, for instance, a patrol of Irish peacekeepers was ambushed in northern Katanga and eight of them died.

75 On 3 December the detainees were transferred to Elisabethville: Gordon, The United Nations in the Congo, p. 86.

76 Gizenga, one of the leaders of the Parti Solidaire Africain (PSA), was an influential figure in the Congolese politics and Lumumba's Deputy Prime Minister.

77 Gordon, The United Nations in the Congo, p. 92.

78 Franck and Carey, 'Working paper', p. 26.

79 Ekpebu, Zaire and The African Revolution, p. 132, nn. 26-7. 


\section{The UN, intra-state peacekeeping and normative change}

80 US statement quoted and criticised by the Indian representative before the Security Council; see S/PV.917 of 10 December 1960, p. 92.

81 Ceylon, Ghana, India, Indonesia, Iraq, Morocco, the UAR and Yugoslavia.

82 The former was rejected by 42 votes to 28 , with 27 abstentions; the latter by 43 to 22 , with 32 abstentions.

83 In the 1990s a similar attitude would be exhibited by dos Santos in Angola and by Sihanouk in Cambodia, both of whom would be recognised by the UN as legitimate office-holders and both of whom would be denied enforcement support against their rivals, but would be given coercive support in the form of sanctions.

84 Gordon, The United Nations in the Congo, p. 94.

85 Algeria, Ghana, Guinea, Mali, Morocco and the UAR. Representatives of Ceylon and Libya also participated.

86 On 12 January 1961, upon allegations that the Belgian authorities in Ruanda-Urundi were actively supporting Kasavubu, the Security Council had met at the Soviet request. However, the Ceylon-Liberia-UAR draft introduced at that meeting had not been adopted although no one actually voted against it (4 votes in favour to 7 abstentions).

87 Hoskyns mentions that as early as the end of October 1960, ONUC was (de facto) authorised to use force if attempts were being made: (a) to force it to withdraw from a position already held; (b) to disarm UN troops; (c) to prevent from carrying out their orders; (d) to violate UN installations or to arrest/abduct UN personnel: see Hoskyns, The Congo Since Independence, pp. 294-5.

88 The Soviet draft resolution of 14 February (S/4706) was rejected with 8 votes against and 2 abstentions. Not even Poland gave its support to the Soviet Union which cast the only affirmative vote.

89 E. W. Lefever, Crisis in the Congo: A United Nations Force in Action (Washington, DC: The Brookings Institution, 1965), p. 57.

90 On 12 December 1960, for instance, Nehru had demanded Lumumba's release, accused Belgians of neoimperialism, and charged the UN with being too passive: see Lefever, Crisis in the Congo, pp. 61-2.

91 The UN had already protected - outside of its specific mandate - a large number of civilians who sought refuge with ONUC during the August 1960 massacres.

92 Lefever, Crisis in the Congo, pp. 68-9.

93 The previous concern over the presence of external interference was reflected only in the second operative paragraph, which urged that measures be taken for the removal of all non-UN foreign personnel from the territory of the Congo.

94 SC Resolution 161A: operative paras 1, 2, 3.

95 SC Resolution 161B: operative paras 1, 2.

96 This interpretation, which argues that the original resolution must have been authorised under Article 40 and not Article 41 or 42, is advanced by Hoskyns, The Congo Since Independence, pp. 120-1.

97 Lefever, Crisis in the Congo, p. 55.

98 The Commission consisted of 12 uncommitted Afro-Asian members. Its president was Jaja Wachuku of Nigeria.

99 Franck and Carey, 'Working paper', p. 29.

100 In March 1961, the Tananarive Conference was convened at Tshombé's initiative. It envisaged a confederated form of government, which was rejected by Léopoldville. In response, Kasavubu organised the Coquilhatville Conference in April-May 1961, and called for the establishment of a federal system, which was strongly opposed by Tshombé. 


\section{The UN in the Congo conflict}

101 GA Resolution 1599, sponsored by 21 Third World governments (Burma, Cambodia, Ceylon, Ethiopia, Federation of Malaya, Ghana, Guinea, India, Indonesia, Iraq, Liberia, Libya, Mali, Morocco, Nepal, Saudi Arabia, Sudan, Togo, the UAR, Yemen and Yugoslavia) was adopted by 61 votes to 5 , with 33 abstentions. The Soviet Union voted in favour, Belgium cast a negative vote, and Britain, France, the United States and the Congo abstained.

102 GA Resolution 1600, sponsored by 16 governments (Burma, Central African Republic, Chad, Ethiopia, Federation of Malaya, Iran, Japan, Libya, Nigeria, Pakistan, Senegal, Somalia, Sudan, Tunisia, Turkey, Upper Volta), was adopted by 60 votes to 16, with 23 abstentions. Britain and the United States voted in favour, the Soviet bloc voted against, and Belgium, France, and the Congo abstained.

103 Ekpebu, Zaire and The African Revolution, p. 100.

104 GA Resolution 1601, sponsored by Ceylon, Ghana, India and Morocco, was adopted by 45 votes to 3, with 49 abstentions. The Congo voted against, while Belgium and the Permanent Five abstained.

105 Hoskyns, The Congo Since Independence, pp. 391-2.

106 Bloomfield argues that, despite all the propaganda to the contrary, this clash occurred only after the severest provocation, and that the UN had no tanks or bombs during the fighting: see Bloomfield, 'Political control of international forces', pp. E-50-1.

107 See Emeka Anyaoku (Commonwealth Secretary-General), Keynote Address at the Conference on African Diplomacy in the 21st Century (London, 24 March 1999), available online at www.thecommonwealth.org/htm/info/info/speeches/1999/ 993-1.htm (3 May 2001).

108 This settlement would not last long.

109 This controversial operation (codenamed Morthor) was initiated by Conor Cruise O'Brien, the Irish diplomat who was at the time the UN representative in Elisabethville.

110 On 11 November 1961, in a particularly brutal incident (reminiscent of Somalia in the 1990s) thirteen Italian aircrew members were killed in Kindu: see Soo, The Malayan Special Force, pp. 55-9.

111 For the recent findings of South Africa's Truth and Reconciliation Commission about whether Hammarskjöld fell victim to a western plot, see 'Letters Say Hammarskjöld Death Western Plot', Reuters (19 August 1998) and 'UN Assassination Plot Denied', $B B C$ (19 August 1998).

112 S/4985/Rev.1. of 20 November 1961.

113 S/4989 of 20 November 1961.

114 By that time, Gizenga too became a 'secessionist' in the eyes of Léopoldville authorities.

115 Preambular para. 4: emphasis original.

116 Operative para. 2.

117 Preambular para. 5.

118 See Lefever, Crisis in the Congo, p. 99.

119 G. M. Williams cited in Lefever, Uncertain Mandate, p. 82.

120 Lefever, Crisis in the Congo, pp. 92-3.

121 Lefever, Crisis in the Congo, p. 99.

122 Franck and Carey, 'Working paper', p. 38.

123 See SCOR, 17th year, Supl. for July, August and September 1962, S/5053/Add.11, para. 91.

124 The ONUC operation was codenamed Grandslam.

125 The message was sent through the Belgian Government channels on 14 January 1963. 